
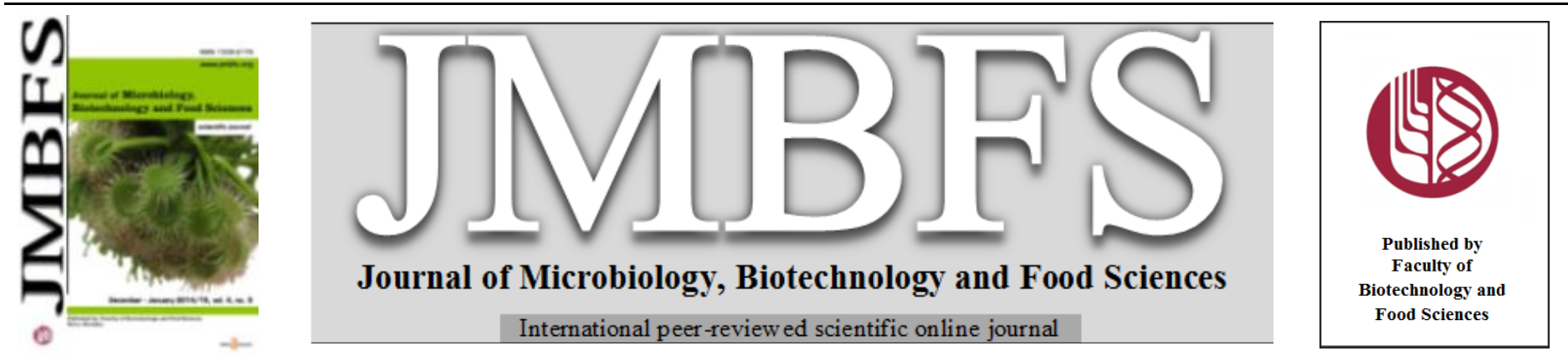

\title{
LACTIC ACID BACTERIA FLORA OF KONYA KUFLU CHEESE: A TRADITIONAL CHEESE FROM KONYA PROVINCE IN TURKEY
}

\author{
Ziba Guley*1, Harun R. Uysal ${ }^{2}$, Sevda Kilic ${ }^{2}$ \\ Address(es): Dr. Ziba Guley, \\ ${ }^{1}$ Ege University, Odemis Vocational School, Milk and Dairy Products Technology Programme, 35760, Odemis, Izmir, Turkey. \\ ${ }^{2}$ Ege University, Faculty of Agriculture, Department of Dairy Technology, 35100 Bornova, Izmir, Turkey.
}

*Corresponding author: zibaguley@yahoo.com

doi: $10.15414 / j m b f s .2014-15.4 .3 .238-242$

\section{ARTICLE INFO}

Received 1. 11. 2013

Revised 14. 10. 2014

Accepted 22. 10. 2014

Published 1. 12. 2014

Regular article

OPEN OACCESS

\begin{abstract}
The aim of this study was to characterize the lactic acid bacteria flora of mature Konya Kuflu cheese. Konya Kuflu cheese is a traditional blue cheese which is produced from raw milk without starter culture addition and mould growth occurs in uncontrolled conditions during its ripening. Lactic acid bacteria (LAB) isolated from 9 mature Konya Kuflu cheese samples were investigated using a combination of conventional biochemical tests, API test kits, and molecular approaches. For some isolates, different results were obtained according to the identification technique. The overall LAB profile of Konya Kuflu cheese samples revealed that Lactobacillus brevis, Lactobacillus paracasei/Lactobacillus casei, Lactobacillus plantarum, Enterococcus faecium, and Enterococcus faecalis are the predominant species. In addition, 1 Pediococcus parvulus and 1 Enterococcus durans were also identified.
\end{abstract}

Keywords: Kuflu cheese, cheese, lactic acid bacteria, identification, PCR/RFLP

\section{INTRODUCTION}

Cheese microflora play an important role in the development of the unique characteristics of each cheese type (Beresford et al, 2001). Due to modern cheese production practices such as pasteurization of milk, use of defined-strain starters, and improved hygiene during manufacture, industrially produced cheeses do not exhibit traditional flavors, and lack some characteristic flavors. Traditionally produced raw-milk cheeses have more intense flavors and extensive flavor profiles. The typical sensorial properties of these cheeses are the results of the diversity of species and strains of local and specific indigenous milk microflora (Rehman et al., 2000; Garabal et al., 2008). In recent years, great many efforts have been made to characterize the flora, especially the lactic acid bacteria (LAB) flora, of many traditional cheeses, with the aim of selecting autochthonous flora to be used in industrial manufacture (López-Díaz et al.,2000; Fortina et al., 2003; Østlie et al., 2004; González et al., 2007; Casalta et al., 2009; Golic et al., 2013; Terzic-Vidojevic et al., 2014). Determination of the natural microbial flora present in traditional dairy products can also help to prevent the loss of microbial biodiversity in typical foods and the subsequent loss of a wide range of cheeses produced through different methods (Fortina et al., 2003). The development of autochthonous cultures specific to a cheese type may ensure protection of organoleptic properties and also guarantee a standard and safer product (Fortina et al., 2003; Dolci et al., 2008). Konya Kuflu Cheese is a traditional mould-ripened cheese variety produced in the Konya province of Turkey. The cheese is produced in eastern part of Turkey, generally from skimmed or partially-skimmed raw sheep's milk without any starter culture addition, and brought to Konya in cylindric plastic bags weighing between 55 and $60 \mathrm{~kg}$. After 40-45 days in cold storage the cheese is cut into blocks, covered with paper, and then left to ripen at room temperatures of $22-23^{\circ} \mathrm{C}$ (varying according to the producers, with temperatures sometimes ranging between 18-23 ${ }^{\circ} \mathrm{C}$ or $25-30^{\circ} \mathrm{C}$ ) until blue-green moulds spontaneously grow on the surface of the cheese. The cheese is well known and consumed in the area by the local people. Although there are no reports of health hazards on people associated with the consumption of Konya Kuflu cheese, these kinds of products always pose risks to human health. Thus, the production of cheese under controlled conditions is essential. For this purpose, knowledge about the indigenous flora has to be acquired in advance. Research on Konya Kuflu cheese is scarce. A recent study (Hayaloglu and Kirbag, 2007) determined the microbiological composition of Kuflu cheese and identified the moulds at the genus and species level, but to date no published information exists on the LAB flora of Konya Kuflu cheese.
The objective of this work was to identify lactic acid bacteria isolated from mature Konya Kuflu cheese by using phenotypic and genotypic methods, in order to obtain preliminary knowledge about the indigenous lactic acid bacteria flora of the cheese. Identification of lactic acid bacteria will be beneficial in selecting those to be used for the preparation of starter cultures for the production of standardized Konya Kuflu cheese.

\section{MATERIAL AND METHODS}

\section{Cheese samples and reference strains}

In total 9 Konya Kuflu cheese samples, collected from Konya province in Turkey, were used for the isolation of lactic acid bacteria. Reference strains used in this study are listed in Table 1.

\begin{tabular}{|c|c|c|}
\hline Reference Strains & Source & Strain no. \\
\hline Lactobacillus casei subsp. casei & NRRL (ARS) & B-1922 ${ }^{\mathrm{T}}$ \\
\hline Lactobacillus casei subsp. casei & NRRL & B-441 \\
\hline Lactobacillus casei subsp. rhamnosus & NRRL & $\mathrm{B}-442^{\mathrm{T}}$ \\
\hline Lactobacillus paracasei subsp. paracasei & NRRL & B-4560 \\
\hline Lactobacillus brevis & NRRL & $\mathrm{B}-4527^{\mathrm{T}}$ \\
\hline Lactobacillus buchneri & NRRL & $\mathrm{B}-1837^{\mathrm{T}}$ \\
\hline Lactobacillus plantarum & NRRL & $\mathrm{B}-4496^{\mathrm{T}}$ \\
\hline Lactobacillus curvatus subsp. curvatus & NRRL & $\mathrm{B}-4562^{\mathrm{T}}$ \\
\hline Enterococcus faecium & NRRL & B-2354 \\
\hline Enterococcus faecalis & CECT & 184 \\
\hline Enterococcus gallinarum & CECT & $970^{\mathrm{T}}$ \\
\hline Enterococcus casseliflavus & NRRL & $\mathrm{B}-3502^{\mathrm{T}}$ \\
\hline Lactococcus lactis subsp. lactis & NRRL & B-1821 \\
\hline Lactococcus lactis subsp. cremoris & NRRL & B-634 \\
\hline Leuconostoc lactis & NRRL & B-3468 \\
\hline Leuconostoc mesenteroides subsp. cremoris & NRRL & $\mathrm{B}-3252^{\mathrm{T}}$ \\
\hline Leuconostoc mesenteroides subsp. dextranicum & NRRL & B- $1146^{\mathrm{T}}$ \\
\hline Leuconostoc mesenteroides subsp. mesenteroides & NRRL & B-512F \\
\hline Pediococcus acidilactici & NRRL & B-1117 \\
\hline Pediococcus damnosus & CECT & 4671 \\
\hline Pediococcus pentosaceus & CECT & $4695^{\mathrm{T}}$ \\
\hline Pediococcus parvulus & CECT & 813 \\
\hline
\end{tabular}

T: Type strains; NRRL: Agricultural Research Service Culture Collection (ARS, NRRL; Peoria, Illinois, USA)

CECT: Spanish Type Culture Collection 


\section{Enumeration and Isolation of LAB}

10 grams of each cheese sample were homogenized in $90 \mathrm{~mL}$ sterile quarterstrength Ringer's solution (Merck 15525) using a Colworth Stomacher 400 blender (Seward Laboratory, U.K.). Serial dilutions up to $10^{-6}$ were prepared and $1 \mathrm{~mL}$ portions of appropriate dilutions $\left(10^{-5}\right.$ and $\left.10^{-6}\right)$ were pour-plated on specific media for the enumeration and isolation of different groups of LAB M17 agar (pH: 7.2) (Terzaghi and Sandine, 1975) was used for lactococci; MRS agar (pH: 5.9-6.0) (De Man et al., 1960) for lactobacilli; MRS agar supplemented with $30 \mu \mathrm{g} \mathrm{m}^{-1}$ of vancomycin (Sigma V-2002) (pH: 5.8) (Mathot et al., 1994) was used for presumptive leuconostocs, and Kanamycin Esculin Azide Agar (Merck KGaA, Darmstadt, Germany) for enterococci. MRS agar supplemented with vancomycin (VMRS) and M17 agar plates were incubated at $30^{\circ} \mathrm{C}$ for $48 \mathrm{~h}$, while MRS agar and Kanamycin Esculin Azide (KEA) agar plates were incubated at $37^{\circ} \mathrm{C}$ for $48 \mathrm{~h}$. To generate microaerophilic conditions, all pour plates except the KEA agar ones were overlaid with a thin layer of the same agar medium used in the plate. Colonies randomly picked from these plates were first streaked on MRS, M17, or KEA agar slants (according to the agar media they were isolated from) and then transferred into appropriate broths. For this purpose MRS, M17, and SF (Streptococcus faecalis) (Atlas, 1995) broths were used. After simple staining, gram staining, and catalase activity tests, gram positive catalase negative isolates, classified according to their morphology, were stored at $-20^{\circ} \mathrm{C}$ in M17 or MRS broth containing $20 \%$ glycerol. Isolates from stock were revitalized by two consecutive transfers in M17 or MRS broth before use.

\section{Phenotypic identification of LAB}

The following tests were performed to phenotypically identify gram positive catalase negative cocci to the species level: growth at different temperatures (10, 40 , and $\left.45^{\circ} \mathrm{C}\right)$ and different $\mathrm{NaCl}$ concentrations $(2 \%, 4 \%$, and $6.5 \%)$, growth at $\mathrm{pH}$ 9.6, production of ammonia from arginine, esculin hydrolysis, and fermentation of carbohydrates. For this purpose, 10 different carbohydrates were used: lactose, $\mathrm{D}(-)$ fructose, $\mathrm{D}(+)$ galactose, maltose, melibiose, salicin, sucrose D(-) sorbitol, raffinose, and L-arbinose. For the identification of lactobacilli and presumptive leuconostocs growth in litmus milk, gas production from glucose, growth at $10,15,37$, and $45^{\circ} \mathrm{C}$, production of ammonia from arginine, esculin hydrolysis, and fermentation tests with 14 carbohydrates (in addition to above mentioned: mannitol, cellobiose, trehalose, amygdaline) were carried out (Rogosa and Sharpe, 1959; Sharpe, 1961; Sharpe et al., 1970; Harrigan and MacCance, 1974).

In addition, 55 representative isolates among 155 isolates were selected for identification to the species level using the API test systems. For lactobacilli and presumptive leuconostoc isolates, $\mathrm{API}^{\circledR} 50 \mathrm{CH}$ (Ref. 50 300) strips with $\mathrm{API}^{\circledR}$ 50CHL (Ref. 50 410) medium (BioMérieux, Istanbul, Turkey) were used, and for cocci, API ${ }^{\circledR} 20$ Strep (Ref. 20 600) (BioMérieux, Istanbul, Turkey) were used The data were evaluated using BioMérieux software (apiweb $^{\circledR}$ stand alone V 1.1.0, BioMérieux)

\section{Genotypic identification of LAB}

\section{PCR/RFLP analysis of 16S rRNA gene- ITS region and 16S rRNA}

Extraction of genomic DNA from isolates and reference strains was performed according to the protocol previously described by Bulut et al. (2005). For the amplification of the 16S rRNA gene-ITS region, forward EGE 1 5'AGAGTTTGATCCTGGCTCAG-3' (Mora et al., 1998) and reverse L1 5'. CAAGGCATCCACCGT-3' (Jensen et al., 1993) primers were used. Amplification of the 16S rRNA gene was performed by using forward EGE1 5'AGAGTTTGATCCTGGCTCAG-3' (Mora $\boldsymbol{e t}$ al., 1998) and reverse EGE2 5'CTACGGCTACCTTGTTACCA-3' primers.

PCR reactions were performed in a $50 \mu \mathrm{l}$ reaction mixture containing $2 \mu \mathrm{l}$ DNA template, $5 \mu \mathrm{l}$ Taq DNA polymerase buffer (Mg free), $3 \mu \mathrm{l}$ of $25 \mathrm{mM} \mathrm{MgCl}_{2}, 5 \mu \mathrm{l}$

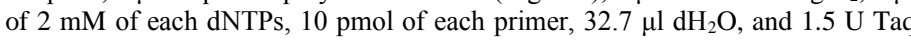
DNA polymerase. All amplification reactions were carried out in a Takara Thermal Cycler (TP600, Takara Bio Inc., Japan) programmed as follows: For the amplification of the 16S rRNA gene-ITS region: an initial denaturation step of 5 min. at $94^{\circ} \mathrm{C} ; 40$ amplification cycles, each consisting of $1 \mathrm{~min}$. denaturation at $94^{\circ} \mathrm{C}, 1 \mathrm{~min}$. annealing at $42^{\circ} \mathrm{C}$, and $1 \mathrm{~min}$. elongation at $72^{\circ} \mathrm{C}$; and finally an extension step of $10 \mathrm{~min}$. at $72^{\circ} \mathrm{C}$

For the amplification of the 16S rRNA gene: an initial denaturation step of $5 \mathrm{~min}$. at $94^{\circ} \mathrm{C} ; 40$ amplification cycles, each consisting of $1 \mathrm{~min}$. denaturation at $94^{\circ} \mathrm{C}$ $1 \mathrm{~min}$. annealing at $56^{\circ} \mathrm{C}$, and $1 \mathrm{~min}$. elongation at $72^{\circ} \mathrm{C}$; and finally an extension step of $10 \mathrm{~min}$. at $72^{\circ} \mathrm{C}$

Two restriction endonucleases, HaeIII and TaqI (MBI Fermentas) were used for the digestion of amplification products. $10 \mu \mathrm{l}$ of purified PCR product were digested overnight with 5 units of each of the enzymes in final reaction volumes of $50 \mu \mathrm{l}$ at $37^{\circ} \mathrm{C}$ (for HaeIII) and $65^{\circ} \mathrm{C}$ (for TaqI). Samples were covered with mineral oil to prevent evaporation. Before and after the digestion, DNA was extracted twice with chloroform and precipitated with ethanol (Bulut $\boldsymbol{e t}$ al. 2005).

Digestion products were separated on $1.6 \%$ agarose gel containing $0.015 \%$ ethidium bromide solution $\left(10 \mathrm{mg} \mathrm{mL}^{-1}\right)$. Gel electrophoresis was carried out first at $60 \mathrm{~mA}$ for $30 \mathrm{~min}$. and then at $80 \mathrm{~mA}$ for $4 \mathrm{~h}$ in $1 \mathrm{xTAE}$ ( $40 \mathrm{mM}$ Tris-acetate, 1 mM EDTA, $\mathrm{pH}$ 8.0) buffer containing $200 \mu \mathrm{l}$ ethidium bromide solution per liter. After electrophoresis, gels were visualized and recorded for further analysis in a gel documentation system (Vilber Lourmat).

\section{S rDNA Sequence Analysis}

Genomic DNA was prepared according to the protocol described above Amplification of 16S rDNA and its sequencing were carried out by an external laboratory (RefGen Biotecnology Lab. Ankara, Turkey). 16S rDNA was completely sequenced in both directions with a BigDye Terminator v3.1 cycle sequencing kit and analyzed with a 3100-Avant genetic analyzer (Applied Biosystems, Foster City, CA). The primers forward EGE1 5'AGAGTTTGATCCTGGCTCAG-3' and reverse EGE2 5' CTACGGCTACCTTGTTACCA-3' were used both for PCR amplification and during sequencing. Sequencing results obtained with forward and reverse primers were then matched. The sequences were determined and compared with known $16 \mathrm{~S}$ rDNA gene sequences in the NCBI (National Center for Biotechnology Information) (www.ncbi.nlm.nih.gov) database by using the BLAST algorithm.

\section{RESULTS AND DISCUSSION}

\section{Enumeration of LAB}

MRS, VMRS, M17 and KEA agar plates of 9 Konya Kuflu cheese samples were counted before isolation. The LAB counts of cheese samples were considerably high, and ranged between 6.64 and $7.43 \mathrm{log} \mathrm{cfu}^{-1}$ on MRS agar, 6.60 and 7.40 $\log \mathrm{cfu} \mathrm{g}^{-1}$ on VMRS agar, 6.62 and $7.80 \log \mathrm{cfu}^{-1}$ on M17, and between 5.17 and $6.54 \log \mathrm{cfu} \mathrm{g}^{-1}$ on KEA agar (Table 2).

Table 2 LAB counts (log cfu $\mathrm{g}^{-1}$ ) on MRS, VMRS, M17, and KEA agars for Konya Kuflu cheese

\begin{tabular}{lcccc} 
Samples & MRS agar & VMRS agar & M17 agar & KEA agar \\
\hline KS & 6.64 & 6.60 & 6.89 & 6.19 \\
$1 \mathrm{KL}$ & 6.77 & 6.74 & 7.33 & 5.74 \\
$2 \mathrm{KL}$ & 6.92 & 6.92 & 7.80 & 6.54 \\
$3 \mathrm{KL}$ & 7.01 & 6.98 & 7.49 & 6.20 \\
$4 \mathrm{KL}$ & 7.43 & 7.40 & 7.77 & 6.32 \\
$5 \mathrm{KL}$ & 7.24 & 7.23 & 6.62 & 6.20 \\
$6 \mathrm{KL}$ & 6.96 & 6.93 & 7.37 & 6.26 \\
$7 \mathrm{KL}$ & 6.88 & 6.83 & 7.27 & 5.17 \\
$8 \mathrm{KL}$ & 6.80 & 6.71 & 7.55 & 5.17 \\
\hline
\end{tabular}

As can be seen from Table 2, counts obtained from MRS agar plates and VMRS agar plates are quite similar. MRS agar supplemented with vancomycin (VMRS) was used for the isolation and enumeration of presumptive leuconostocs However, the identification results showed that almost all of the isolates from this medium (except one pediococcus) were mesophilic lactobacilli. All isolates from MRS agar were mesophilic lactobacilli as well. This explains why counts from the two agar plates were close to each other. M17 agar was used for the enumeration and isolation of lactococci. All gram $(+)$ catalase $(-)$ cocci isolates from M17 agar plates were enterococci, but counts from this medium were higher than the counts obtained from KEA agar. On the basis of the counts obtained and identification results, the M17 agar medium does not seem to be very selective in the isolation of Lactococcus, since it permits the growth of other microorganisms. Besides enterococci, lactobacilli and catalase positive cocci were also observed This medium's poor performance in the isolation of lactococci has been mentioned by other authors (Lòpez-Díaz et al., 2000; González et al., 2007) From our findings, it is obvious that care must be taken when counting colonies grown on these media.

\section{Phenotypic identification}

A total of 176 isolates were obtained from 9 Konya Kuflu cheese samples. Of these 176 isolates, 38 were from MRS agar, 40 from VMRS agar, 52 from KEA agar, and 46 from M17 agar. Morphological examinations showed that all isolates from MRS agar and VMRS agar, with one exception, were in form of coccobacilli or short rods occuring singly, in pairs, or in short chains. The remaining 1 isolate was in tetrad form. In the cultures of some isolates, both ovoid-coccobacilli and rod shapes were observed together, as if they were impure. However, repeated microscopic controls showed that these were pure cultures and were changing their morphology according to the age of the culture. 
Cogan (1996) reported that sometimes, especially in stationary-phase cultures of leuconostocs, both coccal- and rod-shaped cells are found, and as a consequence the culture may look as if it is impure. Dellaglio et al. (1995) stated that, when grown in a glucose medium and on solid medium, leuconostoc cells are elongated and can be mistaken for rods. Some researchers reported that leuconostocs and heterofermentative lactobacilli may not be readily distinguished morphologically, as they can all occur as coccobacilli (Sharpe et al., 1970; Axelson, 1998). In light of the foregoing, it has been very difficult to determine whether isolates from MRS agar and VMRS agar were lactobacillus or leuconostoc. Later, these were distinguished during biochemical and genotypic identifications. Identification results showed that the situation reported by Cogan (1996) for leuconostocs is also valid for mesophilic lactobacilli.

As a result of gram staining, catalase activity, and morphological tests, a total of 155 ( 85 cocci, 70 lactobacilli and/or presumptive leuconostocs and pediococcus) gram-positive catalase negative isolates were subjected to physiological and biochemical tests by using conventional methods. All cocci isolates grew at $10^{\circ} \mathrm{C}$ $45^{\circ} \mathrm{C}$, and $\mathrm{pH} 9.6$, in SF broth containing $0.05 \%$ sodium azide and hydrolyzed esculin. All displayed similar carbohydrate fermentation profiles, differing from each other only in terms of their sorbitol, arabinose, raffinose, and sucrose fermentation abilities. On the basis of these results, the isolates were identified as Enterococcus, even Enterococcus faecium or Enterococus faecalis. However, every isolate couldn't be individually identified. Their inability to grow in media with a $6.5 \% \mathrm{NaCl}$ concentration raised questions of whether they are another Enterococcus species.

All of the lactobacilli and/or presumptive leuconostoc isolates, with a few exceptions, grew both at $10^{\circ} \mathrm{C}$ and $45^{\circ} \mathrm{C}$. Vast majority of them hydrolyzed esculin, while most couldn't produce $\mathrm{NH}_{3}$ from arginine. They displayed considerably different carbohydrate patterns, and some isolates exhibited poor or negative lactose fermentation ability. When the results are compared with phenotypic characteristics reported in the literature, it is difficult to identify isolates to the species level because of some atypical properties. For example, $L b$. plantarum and $\mathrm{Lb}$. brevis isolates grew at $45^{\circ} \mathrm{C}$, and some $\mathrm{Lb}$. brevis isolates fermented lactose.

Some isolates have displayed fermentation profiles that do not exactly match known characteristics of lactobacilli, but are partly similar to those of leuconostocs. LAB isolates displaying similar atypical characteristics have also been reported by many other researchers. (Bulut $\boldsymbol{e t}$ al., 2005), isolated lactococci that demonstrate the ability to grow at $45^{\circ} \mathrm{C}$ and in $6.5 \% \mathrm{NaCl}$ concentrations. On the other hand, Fitzsimons et al. (1999) isolated ribose negative Lb. paracasei and raffinose negative $L b$. plantarum.

When the likely atypical characteristics of isolates were taken into consideration in accordance with the above information, according to biochemical and physiological profiles, of the 70 isolates 11 were $L b$. plantarum, 12 were $L b$. casei, and 18 were Lb. brevis and/or Lb. kefir. 9, 19, and 1 of the remaining 29 isolates were tentatively identified as Lactobacillus spp., Leuconostoc spp., and Pediococcus spp., respectively.

\section{Phenotypic identification with API test kits}

Among the 155 isolates, 55 were selected as representative on the basis of different sources and/or phenotypic characteristics. According to the BioMerieux software, of 30 lactobacilli and presumptive leuconostoc isolates, 13 were Lactobacillus brevis, 9 were Lactobacillus plantarum, 6 were Lactobacillus paracasei subsp. paracasei, 1 was Pediococcus spp., and 1 was Lactococcus lactis subsp. lactis. Of 25 cocci isolates, 14 were Enterococcus faecium, 9 were Enterococcus durans, and 2 were Lactococcus lactis subsp. lactis.

As can be seen from the results, by using API test kits 7 different species that belong to 4 genera were determined, and no Leuconostoc species were identified. However, among these 55 isolates there were some isolates that had been previously identified as Leuconostoc by conventional tests. According to the AP test, isolates M8KL2, MKS5, and V7KL4 belonged to the species Lactococcus lactis subsp. lactis, although these three isolates did not exhibit the typical physiological and/or morphological characteristics of this species. M8KL2 and MKS5 were both cocci shaped but grew at $45^{\circ} \mathrm{C}, \mathrm{pH} 9.6$, and in SF broth that contains $0.05 \%$ sodium azide. V7KL4 was rod shaped. Moreover, M8KL2, MKS5, and V7KL4 were characterized as Enterococcus faecium, Enterococcus durans, and Lactobacillus paracasei subsp. paracasei respectively through $16 \mathrm{~S}$ rDNA sequencing.

Biochemical tests are wholly based on the physiological characteristics and nutritional requirements of microorganisms. Bacteria that have adjusted themselves to different environmental conditions and show atypical characters or have similar nutritional requirements and grow under similar environmental conditions could be misidentified during these tests (Parente et al., 1997; Temmerman et al., 2004; Kao et al., 2007; Abegaz, 2007)

According to the BioMérieux apiweb ${ }^{\circledR}$ database, $90 \%$ of Enterococcus faecium strains and $76 \%$ of Enterococcus durans strains are $\beta$-galactosidase positive. Therefore, the M8KL2 isolate was identified as Lactococcus lactis subsp. lactis (with a probability of $40.9 \%$ ) using API tests, due to its $\beta$ - galactosidase negative activity. V7KL4 showed amygdalin and gentiobiose negative activity. According to the BioMérieux apiweb ${ }^{\circledR}$ database, $99 \%$ of Lactobacillus paracasei subsp. paracasei strains are amygdalin positive and $100 \%$ are gentiobiose positive Thus, V7KL4 was identified, with a probability of $86.2 \%$, as Lactococcus lactis subsp. lactis, of which $75 \%$ of strains are amygdalin positive and $81 \%$ of strain are gentiobiose positive. In contrast to the 16S rRNA sequencing results, identification of a Lactobacillus paracasei isolate as Lactobacillus rhamnosus by API $50 \mathrm{CHL}$ test because of its rhamnose positive reaction has been reported by Kao et al. (2007). Researchers matched this situation against the current BioMérieux database, which suggests that all isolates of this species will be positive by the rhamnose tests, but only $1 \%$ of $L$ b. paracase $i$ can use rhamnose.

\section{Genotypic identification}

From 155 isolates, 79 representatives were subjected to genotypic identification by using PCR/RFLP method. EGE 1 and L1 primers enabled the amplification of the 16S rRNA-ITS region of only 62 isolates. No amplification products were obtained for 16 lactobacilli and/or presumptive leuconostoc isolates and for 1 coccus isolate by using these primers. This was also observed for the $L b$. plantarum, Leuconostoc spp., and Pediococcus spp. (except CECT 813 Pediococcus parvulus) reference strains. Consequently, the 16S rRNA region of these isolates and reference strains could be amplified using EGE1 and EGE 2 primers.

Of 62 isolates, 27 were lactobacilli and presumptive leuconostocs, 1 was Pediococcus, and 34 were enterococci (according to biochemical test results). When RFLP was applied to the 16S rRNA-ITS region of 28 isolates, three different restriction patterns were observed using the HaeIII restriction enzyme. 17 exhibited restriction profiles identical to those of $\mathrm{Lb}$. brevis (NRRL B-4527) and $L b$. casei subsp. casei (NRRL B-441), 10 showed restriction profiles identical to those of $L b$. casei subsp. casei (NRRL B-1922), Lb. paracasei subsp. paracasei (NRRL B-4560), Lb. casei subsp. rhamnosus (NRRL B-442), and Lb. curvatus subsp curvatus (NRRL B-4562), and 1 showed a distinct profile (Fig 1A). On the other hand, the restriction patterns of all 28 isolates obtained with TaqI were uniform and identical to the patterns of reference strains $L b$. brevis (NRRL B-4527), Lb. casei subsp. casei (NRRL B-1922), Lb. paracasei subsp. paracasei (NRRL B-4560), and Lb. casei subsp. rhamnosus (NRRL B-442), and were rather different from the profiles of Lb. casei subsp. casei (NRRL B-441) and Lb. curvatus subsp curvatus (NRRL B-4562) (Fig 1B). HaeIII could differentiate Lb. brevis (NRRL B-4527) and Lb. casei subsp. casei (NRRL B441) from Lb. casei subsp. casei (NRRL B-1922), Lb. paracasei subsp. paracasei (NRRL B-4560), Lb. casei subsp. rhamnosus (NRRL B-442), and Lb. curvatus subsp curvatus (NRRL B-4562), and TaqI could differentiate $L$ b. curvatus subsp curvatus and Lb. casei subsp. casei (NRRL B-441) from Lb. brevis, Lb. casei subsp. casei, Lb. paracasei subsp. paracasei, and Lb. casei subsp. rhamnosus. Neither HaeIII nor TaqI restriction enzymes could discriminate $L b$. casei subsp. casei, Lb. paracasei subsp. paracasei, or Lb. casei subsp. rhamnosus from each other (Fig 1A, B). The V8KL9, V7KL4, and R1KL6 isolates, which showed similar restriction profiles to these three reference strains, were identifed as $L b$. paracasei subsp. paracasei by $16 \mathrm{~S}$ rDNA sequencing. V8KL9 and R1KL6 were identified as $L b$. paracasei subsp. paracasei by API tests as well.

Østlie et al. (2004) and Kao et al. (2007) reported that 16S rDNA sequencing did not seperate between the two important species $L b$. paracasei subsp.paracase and $L b$. casei. In contrast to those researchers' results, in the present study, $L b$. paracasei could be differentiated by API tests and then by $16 \mathrm{~S}$ rDNA sequencing. 1 isolate, identified as Pediococcus spp. on the basis of phenotype and API tests, showed RFLP patterns identical to Lactobacillus spp. rather than Pediococcus parvulus (CECT 813) (Fig 1A, B). This isolate then was identified through 16S rDNA sequencing as Pediococcus parvulus, with an identity certainty of $95 \%$. Enterococcus spp. yielding Lactobacillus spp.-like RFLP band patterns have been reported by Randazzo et al. (2004).

Four enterococci and two lactococci reference strains were used in this study. For 34 cocci isolates, both HaeIII and TaqI endonucleases led to two different restriction patterns, easily distinguishable by gel visualization. Consistent with the biochemical tests, none of them were identical to the restriction profiles of $L c$. lactis subsp. lactis (NRRL B-1821) or Lc. lactis subsp. cremoris (NRRL B-634), and they were identical to the patterns of Enterococcus faecium and Enterococcus faecalis (Fig 2A, B). The best differentiation between the four enterococci reference strains used was obtained through TaqI, as it differentiates Enterococcus faecium and Enterococcus faecalis from each other and from the other reference strains. However, interestingly, some Enterococcus isolates that were identified as Enterococcus faecium with HaeIII restriction enzyme gave Enterococcus faecalis-like restriction patterns with TaqI. On the other hand, some Enterococcus isolates that were identified as Enterococcus faecalis using HaeIII restriction enzyme showed Enterococcus faecium-like restriction profiles with TaqI. Representatives of these isolates were identified as Enterococcus faecium using $16 \mathrm{~S}$ rDNA sequencing. This is a subject of further studies. 




Figure 1 Restriction patterns of the 16S rRNA-ITS gene of 28 isolates (Lactobacilli and Pediococcus) and reference strains digested with the endonucleases HaeIII (A) and TaqI (B). Lane M(1): 100 bp DNA ladder GeneRuler ${ }^{\mathrm{TM}}$, Fermentas; Lane M(2): 1 kb DNA ladder GeneRuler ${ }^{\mathrm{TM}}$, Fermentas.
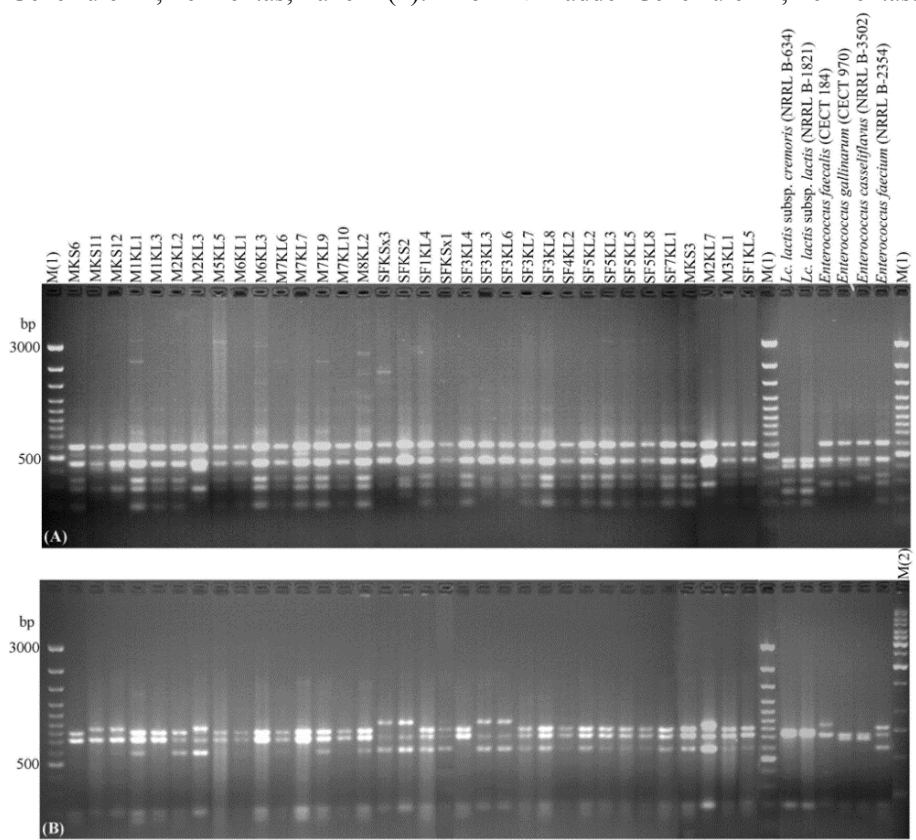

Figure 2 Restriction patterns of the 16S rRNA-ITS genes of 34 enterococci isolates and reference strains digested with the endonucleases Hae III (A) and TaqI (B). Lane M(1): 100 bp DNA ladder GeneRuler ${ }^{\mathrm{TM}}$, Fermentas; Lane M(2): $1 \mathrm{~kb}$ DNA ladder GeneRuler ${ }^{\mathrm{TM}}$, Fermentas.

PCR/RFLP of 16S rRNA with HaeIII and TaqI did not provide differentiation between the majority of the Lactobacillus type strains at the species level. 16 isolates whose $16 \mathrm{~S}$ rRNA could be amplified yielded restriction patterns similar to each other, and all were identical to the profiles of reference strains $L b$. brevis, Lb. casei subsp. case $i, L b$. casei subsp. rhamnosus, Lb. paracasei subsp. paracasei, and Lactobacillus plantarum (data not shown). Therefore, they could only be identified as Lactobacillus spp. Three representatives of these isolates were identified by $16 \mathrm{~S}$ rDNA sequencing as $L b$. plantarum, with an identity certainty of $97 \%$. PCR/RFLP of $16 \mathrm{~S}$ rRNA of 1 coccus isolate showed a Lactobacillus-like restriction profile with HaeIII and a unique profile using the TaqI enzyme (data not shown). 16S rDNA sequencing identified it as Enterococcus durans.

The overall LAB profile of Konya Kuflu cheese samples revealed that Lactobacillus brevis, Lactobacillus paracasei/ Lactobacillus casei, Lactobacillus plantarum, Enterococcus faecium, and Enterococcus faecalis are the predominant species. In addition, 1 Pediococcus parvulus and 1 Enterococcus durans were also identified. The predominance of facultative heterofermentative lactobacilli in cheese has been reported by many researchers (Fitzsimons et al., 1999, 2001; Terzic-Vidojevic et al., 2007, 2009, 2014). On the other hand, enterococci comprise a majority of fresh and ripened cheese microflora (Sarantinopoulos $\boldsymbol{e}$ al., 2001). Enterococci were the only coccal-shaped LAB microflora present in 45-, 60-, and 90-day-old Zlatar cheeses (Terzic-Vidojevic et al., 2007, 2009).

Lactococci develop at the beginning of the cheese-making process and carry out the acidification of the milk, later, during the ripening period of cheese the lactic acid bacteria flora changes, and enterococci and lactobacilli become dominant. This situation seems to be common in most cheese types (López- Díaz et al., 2000). In a study on Valdeón cheese (a Spanish hand-made blue cheese), at the beginning of the process López- Díaz et al. (2000) observed that Lactococcus and Enterococcus were dominant, and leuconostoc and lactobacillus were present in low proportions. During the ripening period, enterococci and, to a lesser extent, lactobacilli and leuconostocs became the major genera in the cheese and lactococci decreased markedly, disappearing by the end of the process. Similar results were obtained by Terzic-Vidojevic et al. $(\mathbf{2 0 0 7}, \mathbf{2 0 0 9})$ during the ripening of Zlatar cheese. We do not have any information about the LAB flora of Konya Kuflu cheese from the beginning of the process; in the present study, cheese samples were collected about 2-3 months or more after production. This explains the predominance of enterococci and mesophilic lactobacilli and absence of lactococci in the samples.

\section{CONCLUSION}

Present research provides preliminary information on the lactic acid bacteria flora of mature Konya Kuflu cheese. Results showed that LAB flora of the mature cheese is mainly composed of species that belong to two genera, Lactobacillus and Enterococcus. Lactobacillus brevis, Lactobacillus paracasei/ Lactobacillus casei, Lactobacillus plantarum, Enterococcus faecium, and Enterococcus faecalis are the predominant species in the cheese. The strains isolated in this study might be used in starter culture combinations in further studies to determine the most suitable combination for Konya Kuflu cheese. Further studies should also investigate the LAB profile of Konya Kuflu cheese from the beginning of production and during the ripening period. The results of this study also revealed that the use of classical methods in combination with molecular techniques is necessary for accurate identification of cheese LAB flora.

Acknowledgments: This work was financially supported by The Scientific and Technological Research Council of Turkey (TUBITAK) (Project no: 105 O 150) and Ege University Scientific Research Projects Commission (Project no: 2004ZRF-014).

\section{REFERENCES}

ABEGAZ, K. 2007. Isolation, characterization and identification of lactic acid bacteria involved in traditional fermentation of Borde, an Ethiopian cereal beverage. African Journal of Biotechnology, 6(12), 1469-1478.

ATLAS, R.M. 1995. Microbiological media for the examination of food, CRC Press, Inc., United States of America, 295p. ISBN 0-8151-0324-7.

AXELSSON, L. 1998. Lactic acid bacteria: classification and physiology. Chapter 1, 1-72, Lactic acid bacteria microbiology and functional aspects. $2^{\text {nd }}$ edition revised and expanded, Eds: Salminen, S. and Atte von Wright. New York-Basel, 617p. ISBN 0-8247-0133-X

BERESFORD, T.P., FITZSIMONS, N.A., BRENNAN, N.L., COGAN, T.M 2001. Recent advances in cheese microbiology. International Dairy Journal, 11, 259-274. http://dx.doi.org/10.1016/s0958-6946(01)00056-5

BULUT, C., GUNES, H., OKUKLU, B., HARSA, S., KILIC, S., COBAN H.S., YENIDUNYA, A.F. 2005. Homofermentative lactic acid bacteria of a traditional cheese, Comlek peyniri from Cappadocia region. Journal of Dairy Research, 72(1), 19-24. http://dx.doi.org/10.1017/s0022029904000536

CASAlTA, E., SORBA J-M., AIGLE, M., OGIER J-C. 2009. Diversity and dynamics of the microbial community during the manufacture of Calenzana, an artisanal Corsican cheese. International Journal of Food Microbiology, 133, 243 251. http://dx.doi.org/10.1016/i.ijfoodmicro.2009.05.022

COGAN, T.M. 1996. History and Taxonomy of Starter Cultures, In Cogan, T.M and Accolas, J.P (Eds.) Dairy Starter Cultures, pp (1-22), Wiley-VCH, Inc., USA ISBN 1-56081-628-7.

DE MAN, J. C., ROGOSA, M., SHARPE, M.E. 1960. A medium for the cultivation of Lactobacilli. Journal of Applied Bacteriology, 23, 130-135. http://dx.doi.org/10.1111/j.1365-2672.1960.tb00188.x

DELLAGLIO, F., DICKS, L.M.T., TORRIANI, S. 1995. The Genus Leuconostoc, In Wood, B.J.B. and Holzapfel, W. H. (Eds.) The Genera of Lactic Acid Bacteria, The Lactic Acid Bacteria, (pp. 235-278) Vol: 2, Blackie Academic and Professional, an imprint of Chapman \& Hall, Glasgow. ISBN 075140215 X http://dx.doi.org/10.1007/978-1-4615-5817-0_7

DOLCI, P., ALESSANDRIA, V., ZEPPA, G., RANTSIOU, K., COCOLIN, L. 2008. Microbiological characterization of artisanal Raschera PDO cheese: Analysis of its indigenous lactic acid bacteria. Food Microbiology, 25, 392-399. http://dx.doi.org/10.1016/j.fm.2007.09.006 
FITZSIMONS, N.A., COGAN, T.M., CONDON, S., BERESFORD, T. 1999 Phenotypic and genotypic characterization of non-starter lactic acid bacteria in mature Cheddar cheese. Applied and Environmental Microbiology, 65(8), 3418 3426 .

FITZSIMONS, N.A., COGAN, T.M., CONDON, S., BERESFORD, T. 2001. Spatial and temporal distribution of non-starter lactic acid bacteria in cheddar cheese. Journal of Applied Microbiology, 90, 600-608. http://dx.doi.org/10.1046/j.1365-2672.2001.01285.x

FORTINA, M.G., RICCI, G., ACQUATI, A., ZEPPA G., GANDINI, A., MANACHINI, P.L. 2003. Genetic characterization of some lactic acid bacteria occurring in an artisanal protected denomination origin (PDO) Italian cheese, the Toma piemontese. Food Microbiology, 20(4), 397-404. http://dx.doi.org/10.1016/s0740-0020(02)00149-1

GARABAL, J. I., RODRÍGUEZ-ALONSO, P., CENTENO, J. A., 2008 Characterization of lactic acid bacteria isolated from raw cows' milk cheeses currently produced in Galicia (NW Spain). LWT - Food Science and Technology, 41(8), 1452-1458. http://dx.doi.org/10.1016/j.1wt.2007.09.004

GOLIĆ, N., ČADEŽ, N, TERZIĆ-VIDOJEVIĆ, A., ŠURANSKÁ, H., BEGANOVİ́, J., LOZO, J., KOS, B., ŠUŠKOVIĆ, J., RASPOR, P., TOPISIROVIC, L. 2013. Evaluation of lactic acid bacteria and yeast diversity in traditional White pickled and fresh soft cheeses from the mountain regions of Serbia and lowland regions of Croatia. International Journal of Food Microbiology, 166, 294-300. http://dx.doi.org/10.1016/j.ijfoodmicro.2013.05.032

GONZÁLEZ, L., SANDOVAL, H., SACRISTÁN, N., CASTRO, J.M., FRESNO, J.M., TORNADIJO, M.E. 2007. Identification of lactic acid bacteria isolated from Genestoso cheese throughout ripening and study of their antimicrobial activity. Food Control, 18, 716-722. http://dx.doi.org/10.1016/j.foodcont.2006.03.008

HARRIGAN, W.F., MACCANCE, M.E. 1974. Laboratory methods in microbiology, (5 ${ }^{\text {th }}$ ed.) Academic Press Inc (London) and New York, $362 \mathrm{p}$ ISBN 12-326050-7

HAYALOGLU, A.A., KIRBAG, S. 2007. Microbial quality and presence of moulds in Kuflu cheese. International Journal of Food Microbiology, 115, 376 380. http://dx.doi.org/10.1016/i.ijfoodmicro.2006.12.002

JENSEN, M.A., WEBSTER, J.A., STRAUSS, N. 1993. Rapid identification of bacteria on the basis of polymerase chain reaction-amplified ribosomal DNA spacer polymorphisim. Applied and Environmental Microbiology, 59, 943-952.

KAO,Y-T., LIU,Y-S., SHYU, Y-T. 2007. Identification of Lactobacillus spp. in probiotic products by real-time PCR and melting curve analysis. Food Research International, 40, 71-79. http://dx.doi.org/10.1016/i.foodres.2006.07.018

LÓPEZ-DÍAZ, T.M., ALONSO, C., ROMÁN, C., GARCÍA- LÓPEZ, M.L., MORENO, B. 2000. Lactic acid bacteria isolated from a hand-made blue cheese. Food Microbiology, 17, 23-32. http://dx.doi.org/10.1006/fmic.1999.0289

MATHOT, A.G., KIHAL, M., PREVOST, H., DIVIES, C. 1994. Selective enumeration of Leuconostoc on vancomycin agar medium. International Dairy Journal, 4, 459-469. http://dx.doi.org/10.1016/0958-6946(94)90059-0

MORA, B., FORTINA, M.G., NICASTRO, G., PARINI, C., MANACHINI, P.L. 1998. Genotypic characterization of thermophilic bacilli: a study on new soil isolates and several reference strains. Research in Microbiology, 149, 711-722. http://dx.doi.org/10.1016/s0923-2508(99)80018-7

ØSTLIE, H. M., ELIASSEN, L., FLORVAAG, A., SKEIE, S. 2004 "Phenotypic and PCR-based characterization of the microflora in Norvegia cheese during ripening. International Journal of Food Microbiology, 94, 287-299. http://dx.doi.org/10.1016/j.ijfoodmicro.2004.01.012

PARENTE, E., ROTA, M.A., RICCIARDI, A., CLEMENTI, F. 1997 Characterisation of natural starter cultures used in the manufacture of Pasta Filata cheese in Basilicata (Southern Italy). International Dairy Journal, 7, 775-783. http://dx.doi.org/10.1016/s0958-6946(97)00093-9

RANDAZZO, C.L., RESTUCCIA, C., ROMANO, A.D., CAGGIA, C. 2004 Lactobacillus casei, dominant species in naturally fermented Sicilian green olives. International Journal of Food Microbiology, 90, 9-14. http://dx.doi.org/10.1016/s0168-1605(03)00159-4

REHMAN, S.U., FOX, P. F., MCSWEENEY, P.L.H. 2000. Methods used to study non-starter microorganisms in cheese: a review. International Journal of Dairy Technology, 53(3), 113-119. http://dx.doi.org/10.1111/j.14710307.2000.tb02672.x

ROGOSA, M., SHARPE, M. E. 1959. An approach to the classification of Lactobacilli, Journal of Applied Bacteriology, 22, 329-340.

SARANTINOPOULOS, P., ANDRIGHETTO, C., GEORGALAKI, M.D., REA, M.C., LOMBARDI, A., COGAN, T.M., KALANTZOPOULOS, G., TSAKALIDOU, E. 2001. Biochemical properties of enterococci relevant to their technological performance. International Dairy Journal, 11, 621-647. http://dx.doi.org/10.1016/s0958-6946(01)00087-5

SHARPE, M.E., 1961. Taxinomie des Lactobacillus, Annales de L' Institut Pasteur de Lille, Extrait du Volume XII, Editions Medicales Flammarion, Paris, $16 \mathrm{p}$.

SHARPE, M. E., FRYER, T. F., SMITH, D. G. 1970. Identification of the lactic acid bacteria, In Gibbs, B.M. and Skinner, F.A. (Eds), Identification methods for microbiologists, Part A, $5^{\text {th }}$ ed., Academic Press-London - New York, 145p ISBN 12-281950-0.

TEMMERMAN, R., HUYS, G., SWINGS, J. 2004. Identification of lactic acid bacteria: culture-dependent and culture independent methods. Trends in Food

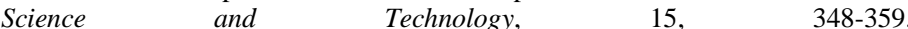
http://dx.doi.org/10.1016/i.tifs.2003.12.007

TERZAGHI, B.E., SANDINE, V.E. 1975. Improved medium for lactic streptococci and their bacteriophages. Applied Microbiology, 29, 807-813.

TERZIĆ-VIDOJEVIĆ, A., VUKASINOVIC, M., VELJOVIC, K., OSTOJIC, M., TOPISIROVIĆ, L. 2007. Characterization of microflora in homemade semi-hard white Zlatar cheese. International Journal of Food Microbiology, 114, 36-42. http://dx.doi.org/10.1016/i.ijfoodmicro.2006.10.038

TERZIĆ-VIDOJEVIĆ, A., VELJOVIC, K., TOLINACKI, M., NIKOLIC, M., OSTOJIC, M., TOPISIROVIC, L. 2009. Characterization of lactic acid bacteria isolated from artisanal Zlatar cheeses produced at two different geographical location. Genetika, 41, 117-136. http://dx.doi.org/10.2298/gensr0901117t

TERZIC-VIDOJEVIC, A., MIHAJLOVIC, S., UZELAC, G., GOLIC, N., FIRA,

Đ., M., KOJIĆ, M., TOPISIROVIĆ, L.J. 2014. Identification and characterization of lactic acid bacteria isolated from artisanal white brined Golija cows'milk cheeses. Archives of Biological Sciences, 66 (1), 179-192. http://dx.doi.org/10.2298/abs1401179 